\title{
PACKAGING AS A PURCHASE DETERMINANTON THE DIETARY SUPPLEMENT MARKET IN POLAND
}

\author{
OPAKOWANIE JAKO DETERMINANT ZAKUPU NA RYNKU SUPLEMENTÓW DIETY W POLSCE
}

\author{
Magdalena Ankiel \\ Poznań University of Economics and Business, \\ Al. Niepodległości 10, 61-875 Poznań, Poland \\ magdalena.ankiel@ue.poznan.pl O ORCID 0000-0003-2594-1600 \\ Paulina Majewska \\ BIOFARM Sp. z 0.0., Wałbrzyska 13, 60-198 Poznań, Poland \\ paulina.majewska86@gmail.com \\ Maciej Urbaniak \\ University of Łódź; \\ Jana Matejki 22/26, 90-237 Łódź \\ maciej.urbaniak@uni.lodz.pl ORCID 0000-0003-4127-1192 \\ DOl: 10.2478/minib-2021-0007
}

\section{ABSTRACT}

Unit packaging of dietary supplements - an inherent element of their manufacturing, without which they would be impossible to market - has numerous interlocking functions to fulfil, including the protective, transport, information, functional, ecological and marketing functions. The information function, however, is one of the priority functions of dietary supplement packaging. In the era of the continual development of online and selfservice stores (including pharmacies), such packaging has become one of the key sources of information about dietary supplements' features and properties, while also serving as a brand image creator and a carrier of promotional information. This raises the questions of whether and to what extent the unit packaging of dietary supplements influences the purchasing decisions of consumers, what features and elements of such packaging are crucial for consumers in the purchasing process, and what significance supplement packaging has in the purchasing process against the background of other purchasing determinants. Seeking to address these questions, herein we present selected results of an original study conducted in 2019 with a purposely selected sample of 468 dietary supplement consumers in Poland, whose main purpose was to identify the role and significance of packaging as a determinant of purchase in relation to three selected categories of dietary supplements..

Key words: packaging, dietary supplements, purchasing decisions, purchase determinants 


\section{ABSTRAKT}

Opakowania jednostkowe są nieodłącznym elementem produktów takich jak suplementy diety, bez których nie byłoby możliwe wprowadzanie na rynek suplementów. Opakowania suplementów diety powinny pełnić liczne, zazębiające się funkcje, do których należą: ochronna, transportowa, informacyjna oraz funkcjonalna, ekologiczna i marketingowa. Jedną z priorytetowych funkcji opakowań suplementów diety jest funkcja informacyjna. W dobie rozwoju sklepów internetowych i sklepów samoobsługowych (w tym aptek) opakowanie jest jednym z kluczowych źródeł informacji o cechach i właściwościach suplementu diety, a poprzez swój wizerunek staje się wizerunkiem marki twórca i nośnik informacji promocyjnej. Wobec powyższego zasadne jest ustalenie, czy i w jakim stopniu opakowanie jednostkowe suplementu diety wpływa na decyzje zakupowe konsumentów, jakie cechy i elementy opakowania są kluczowe dla konsumentów w procesie zakupowym, jakie jest znaczenie opakowanie suplementu w procesie zakupowym na tle innych uwarunkowań zakupowych. W artykule przedstawiono wybrane wyniki badań własnych przeprowadzonych na celowo dobranej próbie 468 konsumentów suplementów diety w Polsce w 2019 roku, których gtównym celem było określenie roli i znaczenia opakowania jako determinanty zakupu w odniesieniu do trzech wybranych kategorii suplementów diety.

Słowa kluczowe: opakowania, suplementy diety, decyzje zakupowe, uwarunkowania zakupowe

JEL: D12, D91, J14, 039

\section{Introduction}

Dietary supplements have for years constituted one of the most stable, promising and innovative markets, both in the world and in Poland. Worldwide, the dietary supplements market was valued at USD 96 billion in 2017, with forecasts anticipating a further $6.9 \%$ growth over the next five years (https://www.researchandmarkets.com). The growing supply produced by dietary supplement manufacturers is being fuelled by demand from consumers who - in an era of ever-increasing risk of modern-day "diseases of civilization" - are growing increasingly aware of the importance of prevention in protecting their own health. In Poland, the market value is estimated in 2018 at PLN 5.363 billion, while the forecast for 2023 is PLN 
6.504 billion (https://www.researchandmarkets.com/). The main reasons for positive forecasts for market development are the increased interest in supplements and the ever-broader range of such products.

From a formal point of view, dietary supplements are not considered medicinal products, although they are very often confused with over-thecounter medications. A dietary supplement has been defined as: "a food which is intended to supplement a normal diet, being a concentrated source of vitamins or minerals or other substances having a nutritional or other physiological effect, single or complex, marketed in a form enabling dosage, excluding products having properties of a medicinal product within the meaning of the provisions of the pharmaceutical law" (Polish Food Safety Act, 2006; EU Food Supplements Directive, 2002). Dietary supplements may contain vitamins and minerals that are naturally present in food and are consumed as part of it, as well as other substances exhibiting a nutritional or other physiological effect (Polish Food Safety Act, 2006).

Unit packages are an integral part of the dietary supplements market (Jamal et al., 2012). In the case of dietary supplements, the packaging primarily protects the packaged product against the negative influence of external factors and enables its distribution in the logistics chain, but it also constitutes a tool for marketing activities (Shah et al., 2013). The potential of dietary supplement packaging (generated by elements such as packaging material, design, closing systems, labelling, colours and graphics) makes them an effective tool for marketing activities (Ankiel-Homa, 2012). From the consumer's point of view, the product packaging is a source of numerous kinds of necessary information about the supplement, a brand image identifier and one of the main purchasing determinants (Butkeviciene et al., 2008).

Properly designed packaging plays an important role in the purchasing behaviour of consumers, particularly in the process of making purchasing decisions (Granger and Billson, 1972; McDaniel and Baker, 1977; Homer and Gauntt, 1992; Underwood et al., 2001; Kuvykaite et al., 2009; Rambabu and Porika, 2020). From the consumer's point of view, packaging of dietary supplements is a source of important information about the product, which is of particular importance in the purchasing process (Butkeviciene et al., 2008; Wang, 2013; Bahrainizad and Rajabi, 2018; Bigoin-Gagnan and 
Lacoste-Badie, 2018). Packaging of dietary supplements must meet increasing requirements - in addition to fulfilling the essential functions (protective, information and transport) it needs to be characterized by modern design, innovative construction and graphic solutions, high utility for consumers and environmental friendliness (Auttarapong, 2012; Casillas, 2013; Ankiel-Homa, et al., 2011).

The key factors favouring the development of packaging on the dietary supplements market include the following (Ankiel and Walenciak, 2018; Ankiel and Sojkin, 2018; Jamal et al., 2012; Grundey, 2010; Lee et al., 2008; Barska and Wyrwa, 2017):

- new trends in consumer behaviour (e.g. increased care for health and appearance) that generate increased consumption of dietary supplements;

- an aging society, which results in greater demand for products addressed to senior consumers;

- the development of innovative, self-service sales formats (mainly convenience stores), boosting the demand for modern packaging as an effective tool for creating a product brand and higher sales;

- environmental and ecological trends and requirements driving the development of environmentally friendly packaging;

- the dynamic development of e-commerce, boosting the demand for packaging that projects the image of the product/brand, with high information value and maximally protecting the packed product during transport.

Because, as has been mentioned, packaging is one of the key factors influencing consumer purchasing decisions, the design process for packaging should be carried out simultaneously in relation to the packed product, taking into account the needs and requirements of consumers (Abdullahi, 2018; Moskowitz et al., 2009; Perry and Cochet, 2009). As such, in this study, we resolved to try to better identify the impact of packaging (and its components) on purchasing decisions made by consumers on the dietary supplements market in Poland. 


\section{Materials and methods}

The main purpose of the study was to identify and evaluate the importance of packaging as a determinant affecting the purchase of selected dietary supplements in Poland. In turn, the specific research objectives were specified as follows:

- identification of factors influencing the selection of tested dietary supplements, taking into account the differences within selected product groups;

- assessment of the importance of unit packaging during purchase;

- identifying the significance of packaging elements and features affecting the purchase decision;

- diagnosis of respondents' tendency to opt out of purchasing due to inadequate packaging.

The study was conducted using the CAWI (Computer-Assisted Web Interview) online interview method. We considered the 3 categories of dietary supplements which, out of 12,556 products registered in Poland, show the strongest growth in sales (GIS, 2017):

- strengthening the hair, skin and nails;

- containing a magnesium preparation;

- supporting weight loss.

The survey was conducted in the period from April 2017 to May 2019 on a sample of 468 respondents in Poland. Sample selection was by deliberate choice: the survey included consumers declaring systematic consumption of dietary supplements from the studied categories.

\section{The importance of packaging as determinants of the purchase of dietary supplements}

The main objective of this study was to diagnose whether packaging is an important purchasing determinant for dietary supplements, to what extent 
and for which product categories (including any differences between hair, skin and nail strengthening supplements, magnesium supplements and products for slimming). To this end, the respondents were asked about the importance of packaging for them when shopping in each of the product groups studied. The respondents' answers showed clear differences by product category: packaging in the purchasing process was reported to be most important in the case of skin, hair and nail strengthening supplements (average 3.54); with weight loss supplements in second place (average 2.92 ), followed by products containing magnesium (average 2.68). These findings show that, interestingly, unit packaging is most important for consumer decisions when buying products that are directly related to the external appearance of the consumer (strengthen hair, skin and nails, and for weight loss).

The study also sought to identify the importance of packaging in the purchase process of selected dietary supplements against other purchasing factors. The results show noticeable differences between the factors determining the purchase of dietary supplements in various product categories. People looking for magnesium products, i.e. those not directly affecting the appearance of the consumer, but rather bearing upon their health and good physical condition, are most susceptible to the suggestions of pharmacists. For people looking for supplements that support weight loss, recommendations of friends are the most important. In turn, for people looking for products to strengthen the hair, skin and nails, the most important is the price / profitability of the purchase.

The most important factor influencing the choice of the tested dietary supplements strengthening the hair, skin and nails are the product's features and properties (average 4.42). Next, respondents pointed to the product price (average 4.12), recommendation (average 3.71), advertisement (average 3.44) and a pharmacist's suggestion (average 3.26).

In the category of dietary supplements supporting slimming, the results are different: most important for the consumer in the purchase process are the product features and properties (average 4.44), price (average 3.69), recommendation (average 3.39), and advertisement (average 3.24). The place of sale was indicated as the least important (average 2.28). On the other hand, in the case of magnesium supplements, the most important purchase determinants are the product features and properties (an average of 4.67 indications), price (average 4.27), recommendations (average 3.48) 
and advertisement (average 3.26). As the data presented in Table 1 show, for each of the studied groups of dietary supplements, packaging turned out to be a factor of little importance in the purchase process (average 3.06; 2.79; 2.88) compared to other factors definitely more important for the consumer, such as price, product properties or a pharmacist's suggestion.

\section{Table 1. The importance of packaging in the process}

of purchasing dietary supplements against the background of other factors

\begin{tabular}{|c|c|c|c|c|c|}
\hline \multicolumn{2}{|c|}{$\begin{array}{c}\text { Hair, skin and nail } \\
\text { strengthening supplements }\end{array}$} & \multicolumn{2}{|c|}{$\begin{array}{c}\text { Supplements supporting } \\
\text { slimming }\end{array}$} & \multicolumn{2}{|l|}{$\begin{array}{l}\text { Magnesium } \\
\text { supplements }\end{array}$} \\
\hline $\begin{array}{c}\text { Purchasing } \\
\text { determinants }\end{array}$ & Average & $\begin{array}{l}\text { Purchasing } \\
\text { determinants }\end{array}$ & Average & $\begin{array}{c}\text { Purchasing } \\
\text { determinants }\end{array}$ & Average \\
\hline Product features & 4.42 & Product features & 4.44 & Product features & 4.67 \\
\hline Price & 4.12 & Price & 3.69 & Price & 4.27 \\
\hline Recommendation & 3.71 & Recommendation & 3.39 & Recommendation & 3.48 \\
\hline Advertisement & 3,44 & Advertisement & 3.24 & Advertisement & 3.26 \\
\hline Pharmacist's suggestions & 3.26 & Pharmacist's suggestions & 3.10 & Pharmacist's suggestions & 3.11 \\
\hline Habit & 3.22 & Habit & 2.81 & Habit & 3.10 \\
\hline Sales promotion & 3.08 & Sales promotion & 2.80 & Sales promotion & 3.07 \\
\hline Packaging & 3.06 & Packaging & 2.79 & Packaging & 2.88 \\
\hline Brand & 2.71 & Brand & 2.61 & Brand & 2.60 \\
\hline Product availability & 2.65 & Product availability & 2.54 & Product availability & 2.38 \\
\hline Place of sale & 2.48 & Place of sale & 2.28 & Place of sale & 2.32 \\
\hline
\end{tabular}

Source: own research

\section{Assessment of selected elements and features of dietary supplement packaging}

In the course of the study, the significance of elements and features of the tested dietary supplement packaging that influence consumers when shopping was also assessed. The results are presented in Table 2.

Definitely the most important factor for consumers, in each of the product groups studied, is the information on the packaging. Clear packaging containing information relevant to consumers is the most important for people buying supplements. Secondly, the functionality of the 
packaging is important. In the third and fourth place among the most frequently appearing responses were interchangeable aesthetics of the workmanship or ecological aspects of the packaging. The least important factors are the shape of the packaging and the design of the packaging.

\section{Table 2. Elements and features of packaging affecting purchasing decisions for dietary supplements}

\begin{tabular}{l|l|l|l|l|l}
\multicolumn{2}{c}{$\begin{array}{c}\text { Hair, skin and nail } \\
\text { strengthening supplements }\end{array}$} & \multicolumn{2}{c}{$\begin{array}{c}\text { Supplements supporting } \\
\text { slimming }\end{array}$} & \multicolumn{2}{c}{$\begin{array}{c}\text { Magnesium } \\
\text { supplements }\end{array}$} \\
\hline $\begin{array}{c}\text { Features and } \\
\text { and components } \\
\text { of packaging }\end{array}$ & Average & $\begin{array}{c}\text { Features and } \\
\text { and components } \\
\text { of packaging }\end{array}$ & Average & $\begin{array}{c}\text { Features and } \\
\text { and components } \\
\text { of packaging }\end{array}$ & Average \\
\hline Information & 3.39 & Information & 3.95 & Information & 4.04 \\
Functionality & 3.42 & Functionality & 3.19 & Functionality & 3.30 \\
Aesthetics of performance & 3.34 & Aesthetics of performance & 3.18 & Aesthetics of performance & 3.21 \\
Ecological aspects & 3.15 & Ecological aspects & 3.13 & Ecological aspects & 3.18 \\
Packaging material & 2.75 & Packaging material & 2.66 & Packaging material & 2.70 \\
Graphics & 2.64 & Graphics & 2.64 & Graphics & 2.52 \\
Color & 2.63 & Color & 2.55 & Color & 2.50 \\
Construction form & 2.37 & Construction form & 2.36 & Construction form & 2.35 \\
Shape & 2.31 & Shape & 2.33 & Shape & 2.33 \\
\hline
\end{tabular}

Source: own research

One of the objectives of the study was to investigate answers to the question: "Have you ever decided against buying a dietary supplement because of its inadequate packaging?". The results indicated that $53.85 \%$ of respondents answered this in the negative. One out of every four respondents (26.28\% of answers) answered affirmatively, while $19.87 \%$ of respondents gave the answer "I don't recall". Participants who responded affirmatively were asked to name a maximum of three main reasons for their opting not to make the purchase. The results indicate that by far the most common motive for withdrawing from the purchasing process was a lack of comprehensive product information (56.90\% of responses). The next clear indication was illegible information on the packaging $(46.55 \%$ of responses). Further places were taken by: poor packaging aesthetics (24.14\%), impractical closure (24.14\%), inadequate capacity (too big / too 
small; 20.69\%). A small percentage of respondents indicated as a reason "packaging difficult to dispose of after use of the product" and "uncomfortable design / packaging shape" (only 6.9\%), while "unsuitable packaging material / material" was indicated by $3.45 \%$.

The results clearly show that the main negative factor motivating decisions not to follow through with a possible purchase are incorrectly designed packaging of dietary supplements, especially in the product information layer. Product features and properties have been recognized by respondents as one of the key purchasing determinants, so it is important that this information should be correctly, reliably and legibly placed on the packaging of the dietary supplement.

\section{Conclusions and recommendations}

Herein we presented some findings from an original study with a selected sample of 468 dietary supplement consumers in Poland, carried out in order to gain more into the role and significance of packaging as a determinant of purchase in relation to three selected categories of dietary supplements. Overall, we found that, in the case of dietary supplements, while unit packaging is not a crucial purchasing determinant (the most important factors being price, product properties and features, and a pharmacist's recommendation), it is nevertheless still a fairly important factor influencing the selection and purchase of tested products. Moreover, we found that in relation to the three categories of dietary supplements studied, packaging is most important for supplements intended to aid the skin, hair and nails. Close analysis of the individual features and elements of packaging that affect the purchase of the studied categories of dietary supplements showed that the most important factors for consumers are the information placed on the packaging, the functionality of the packaging (e.g. ease of opening / closing) and the aesthetics of the packaging. These factors do not differ in relation to the three categories of dietary supplements analyzed.

Thus, in the case of hair, skin and nail strengthening supplements, the functionality of the packaging turned out to be its most important aspect, and in the case of supplements supporting slimming and magnesium 
supplements, the information contained therein is the most important element of the packaging in the opinion of consumers.

The results of our study indicate that consumers are prone to decide not to buy a dietary supplement if they feel that the preparation has an inadequate packaging (1/4 of respondents have made such a decision). The main reason for withdrawing from a purchase was a lack of reliable and comprehensive information about the product properties on the packaging and inadequate aesthetic values. This very clearly indicates how important it is for the process of designing the visual layer of dietary supplement packaging to be done with due diligence, based on the preferences and expectations of target consumers.

The dynamically growing market of dietary supplements globally, as well as in Poland, is giving rise to an ever-greater need for such research revealing more about how consumers perceive dietary supplement packaging, and how such packaging fulfils its various interrelated functions - especially the information function. In the era of the continual development of online and self-service stores, such packaging has become one of the key sources of information about dietary supplements. Our study on the determinants of the choice of dietary supplements within three separate product groups (strengthening the hair, skin and nails; supporting weight loss; containing magnesium) is admittedly only preliminary due to the selection and limited size of the research sample, but it offers a promising prelude to other, more advanced research.

\section{References}

1. Abullahi, N. (2018). Advances in food packaging technology - A review. Journal of Postharvest Technology, 06(4), 55-64.

2. Ankiel, M., \& Sojkin, B. (2018). Wartość informacyjna opakowań kosmetyków jako determinanta decyzji nabywczych konsumentów. Handel Wewnętrzny, 4(375), vol. II, 296-306.

3. Ankiel, M., \& Walenciak, M. (2018). Rola opakowań produktów w innowacyjnych formach sprzedaży. In M. Paździor, J. Żuchowski, \& R. Zieliński (Eds.), Wybrane problemy jakości wyrobów przemystowych (pp. 97-104). ISBN 978-83-7351-848-3.

4. Ankiel-Homa, M. (2012). Wartość komunikacyjna opakowań jednostkowych. Wydawnictwo Uniwersytetu Ekonomicznego w Poznaniu. ISBN: 978-83-7417-700-9 
5. Ankiel-Homa, M., Czaja-Jagielska, N., \& Korzeniowski A. (2011). Innowacje w opakowalnictwie. Wydawnictwo Uniwersytetu Ekonomicznego w Poznaniu. ISBN: 97883-7417-539-5

6. Auttarapong, D. (2012). Packaging design expert system based on relation between packaging and perception on consumer. Procedia Engineering, 32. 307-314. https://doi.org/10.1016/j.proeng.2012.01.1272.

7. Bahrainizad, M., \& Rajabi, A. (2018). Consumers' perception of usability of product packaging and impulse buying: Considering consumers' mood and time pressure as moderating variables. Journal of Islamic Marketing, 9(2), 262-282. https://doi.org/10.1108/JIMA-04-2016-0030.

8. Barska, A., \& Wyrwa, J. (2017). Innovations in the food packaging market: Intelligent packaging - a review. Czech Journal Food Science, 35, 1-6. https:/doi.org/ 10.17221/268/2016-CJFS.

9. Bigoin-Gagnan, A., \& Lacoste-Badie, S. (2018). Symmetry influences packaging aesthetic evaluation and purchase intention. International Journal of Retail \& Distribution Management, 46(11/12), 1026-1040. https:/doi.org/10.1108/IJRDM-06-2017-0123.

10. Butkeviciene, V., Stavinskiene J., \& Rutelione, A. (2008). Impact of consumer package communication on consumer decision making process. The Engineering Economics, 1(56), 57-65.

11. Casillas, C. (2013). Food packaging's role in food safety. Food Processing Magazine, 5.

12. EU Food Supplements Directive. (2002). Directive 2002/46/EC of the European Parliament and of the Council of 10 June 2002 on the approximation of the laws of the Member States relating to food supplements (Text with EEA relevance). Official Journal L 183, 12/07/2002 pp. 0051-0057

13. GIS. (2017). https://rejestrzp.gis.gov.pl/index.php/przegladaj/2017 (retrieved 2018.08.20).

14. Granger, C. W. J., \& Billson, A. (1972). Consumers' attitudes toward package size and price. Journal of Marketing Research, 9(3), 239-248. https://doi.org/10.1177/ 002224377200900301.

15. Grundey, D. (2010). Functionality of product packaging: Surveying consumers' attitude towards selected cosmetic brands. Economics \& Sociology, 3(1), 87-103.

16. Homer, P. M., \& Gauntt, S. G. (1992). The role of imagery in the processing of visual and verbal packaging information. Journal of Mental Imagery, 16(3-4), 123-144.

17. Research and Markets (n.d.). Global Dietary Supplements Market - Growth, Trends, and Forecast (2019-2024). https://www.researchandmarkets.com/reports/4602409/globaldietary-supplements-market-growth (retrieved 2018.07.10).

18. Jamal, A., Khan, M .S., \& Tsesmetzi, M. S. (2012). Information cues roles in product evaluations: The case of the UK cosmetics market. Journal of Strategic Marketing, 20(3), 249-265. https://doi.org/10.1080/0965254X.2011.643919.

19. Kuvykaite, R., Dovaliene, A., \& Navickiene, L. (2009). Impact of package elements on consumers' purchase decision. Economics and Management, 14, 441-447.

20. Lee, D. S., Yam, K. L., Piergiovanni, L. (2008). Food Packaging Science and Technology. CRC Press, Taylor \& Francis Group. ISBN 9780824727796..

21. McDaniel, C., \& Baker, R. C. (1977). Convenience food packaging and the perception of product quality. Journal of Marketing, 41(4), 57-58. https:/doi.org/10.1177/ 002224297704100406. 
22. Moskowitz, H. R., Saguy, I. S., \& Straus, T. (2009). Part IV: Proper packaging and preparation. In An integrated approach to new food product development. CRC Press, Boca Raton. https://doi.org/10.1201/9781420065558.

23. Perry, C., \& Cochet, M. (2009). Consumer packaged goods product development process in the 21st century: Product lifecycle management emerges as a key innovation driver. In H. R. Moskowitz, I. S. Saguy, \& T. Straus (Eds.), An integrated approach to new food product development (Part III: The Right Food, Chapter 8). CRC Press, Boca Raton. https://doi.org/10.1201/9781420065558.

24. Rambabu, R., \& Porika, R. (2020). Packaging strategies: knowledge outlook on consumer buying behavior. Journal of Industry-University Collaboration, 2(2), 67-78. https://doi.org/10.1108/JIUC-10-2019-0017.

25. Research and Markets (n.d.). Global Dietary Supplements Market - Growth, Trends, and Forecast (2019 - 2024). https://www.researchandmarkets.com/reports/4602409/globaldietary-supplements-market-growth (retrieved 2018.07.10).

26. Shah, S., Ahmad, A., \& Ahmad, N. (2013). Role of packaging in consumer buying behavior: A study of University Students of Peshawar Region KPK Pakistan. International Review of Basic and Applied Sciences, 1(2), 35-41.

27. Underwood, R. L., Klein, N. M., \& Burke, R. R. (2001). Packaging communication: Attentional effects of product imagery. Journal of Product \& Brand Management, 10(7), 403-422. https://doi.org/10.1108/10610420110410531.

28. Polish Food Safety Act. (2006). Ustawa o bezpieczeństwie żywności i żywienia z dnia 25 sierpnia 2006 r. (Dz.U. z 2006 r. Nr 171, item 1225 as amended)

29. Wang, E. (2013). The influence of visual packaging design on perceived food product quality, value, and brand preference. International Journal of Retail and Distribution Management, 41(10), 805-816. https://doi.org/10.1108/IJRDM-12-2012-0113.

Magdalena Ankiel - is a Professor at the Poznań University of Economics and Business. She is employed in the Product Marketing Department at the Institute of Marketing. Her research and teaching interests focus on consumer behavior, innovation design and development and the informative value of packages.

Maciej Urbaniak - is a Professor of Economic Sciences, employed at the Faculty of Management of the University of Łódź. As an academic lecturer and researcher, her scientific interests are supply chain management, quality management, marketing.

Paulina Majewska - is a product manager at the company Biofarm sp. z 0.0. She completed her doctoral studies at the Poznań University of Economics and Business. 